\title{
Inflammation and regeneration in cross-organs
}

Seiji Okada ${ }^{*}$ and Toru Ogata ${ }^{2}$

Keywords: Inflammation, Tissue repair, Regeneration

The inflammation that accompanies injury and disease is a defense reaction, constituting an important part of the natural innate immune response. In any organ, inflammation is necessary for the healing process to reduce the size of a damaged or necrotic area and replace it with new tissue. When the necrotic area is replaced by new functional tissue, it is called regeneration; when it is instead replaced with abnormal scar tissue with prolonged inflammation, it is called fibrosis. Most organs will heal using a mixture of both mechanisms, and the inflammatory response is closely associated with these processes. The inflammation itself can support tissue protection and regeneration; however, it can also lead to further damage and dysfunction, like a double-edged sword.

It is often difficult to recognize whether inflammation is harmful or beneficial for organ regeneration, since inflammatory reactions can be clinically, pathologically, and physiologically variable, depending on the cause and stage. In addition, a variety of inflammatory mediators finely orchestrate inflammation through extremely complicated cellular interactions, which makes inflammation nearly impossible to understand completely. Inflammation can be either therapeutic or exacerbating in different situations or organs, even when executed in the exact same manner.

However, the act of mixing different insights from mutually irrelevant fields (organs or disease) can occasionally lead to the development of new insights. Indeed, in this manner, I have identified a new mechanism in the healing process following traumatic central nervous system (CNS) injury by examining the skin wound healing process [1]. Keratinocyte migration via Stat3 signaling was found to be responsible for skin wound healing, and Stat3 deficiency results in compromised healing [2]. Similar to this, Stat3 was found to be essential after spinal cord injury for the migration of astrocytes, the most abundant cell population in the CNS.

We invited the leading researchers on inflammatory disease in several different organs to participate in this review. Dr. Shichita's group summarized their recent findings regarding the role of post-ischemic inflammation in ischemic stroke pathology. I reviewed a pathophysiological role of acute inflammation in spinal cord injury. Dr. Yamada's group discussed the relationship between inflammatory cells and lung injury/repair mechanisms. Dr. Miyajima expounded on new techniques for examining the process of liver regeneration and its mechanisms. Dr. Tamai reviewed the role of high-mobility group box 1 (HMGB1) and the associated functional cells in skin regeneration. I would like to express my gratitude to the distinguished researchers who contributed to this special issue. I sincerely hope that these review articles will offer some novel insight beyond the boundaries of the organ to scientists in the field of inflammation and regeneration.

\section{Authors' contributions}

SO and TO prepared the manuscript. Both authors read and approved the final manuscript.

\section{Competing interests}

The authors declare that they have no competing interests.

\footnotetext{
*Correspondence: seokada@ortho.med.kyushu-u.ac.jp

'Department of Advanced Initiatives, Graduate School of Medical Sciences, Kyushu University, 3-1-1 Maidashi, Higashi-ku, Fukuoka 812-8582, Japan Full list of author information is available at the end of the article
} 


\section{Author details}

'Department of Advanced Initiatives, Graduate School of Medical Sciences, Kyushu University, 3-1-1 Maidashi, Higashi-ku, Fukuoka 812-8582, Japan. ${ }^{2}$ Department of Rehabilitation for the Movement Functions, Research Institute, National Rehabilitation Center for Persons with Disabilities, Saitama, Japan.

Received: 4 June 2016 Accepted: 6 July 2016

\section{Published online: 05 October 2016}

\section{References}

1. Okada S, Nakamura M, Ishii K, et al. Conditional ablation of Stat3 or Socs3 discloses a dual role for reactive astrocytes after spinal cord injury. Nat Med. 2006;12:829-34.

2. Sano S, Itami S, Takeda K, et al. Keratinocyte-specific ablation of Stat3 exhibits impaired skin remodeling, but does not affect skin morphogenesis. EMBO J. 1999;18:4657-68.

\section{Submit your next manuscript to BioMed Central} and we will help you at every step:

- We accept pre-submission inquiries

- Our selector tool helps you to find the most relevant journal

- We provide round the clock customer support

- Convenient online submission

- Thorough peer review

- Inclusion in PubMed and all major indexing services

- Maximum visibility for your research

Submit your manuscript at www.biomedcentral.com/submit 